CURRENT BIOCHEMISTRY

ISSN: $2355-7877$

Journal Homepage: http://biokimia.ipb.ac.id

Journal Email: current.biochemistry@ipb.ac.id

\title{
Induksi Ekspresi Gen Sitokin/Kemokin pada Sel Makrofag Manusia yang Dipapar Virus Dengue Isolat Indonesia
}

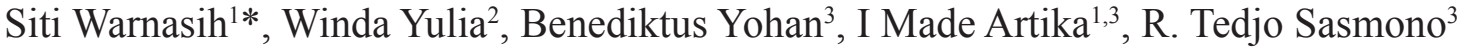 \\ ${ }^{1}$ Departemen Biokimia, Institut Pertanian Bogor (IPB), Bogor 16680, Indonesia \\ ${ }^{2}$ Fakultas Kedokteran, Universitas Syiah Kuala, Aceh 23111, Indonesia \\ ${ }^{3}$ Lembaga Biologi Molekuler Eijkman, Jakarta 10430, Indonesia
}

Received: 23 October 2014; Accepted: 24 December 2014

*Corresponding author: Siti Warnasih; Departemen Biokimia, Jl. Agatis Gd. Fapet Lt. 5, Wing 5, Bogor 16680; Telp/Fax. +62251-8423267; Email: siwa47@gmail.com.

\section{ABSTRACT}

Dengue is one of the world's most important arbovirus disease. Dengue pathogenesis has not been yet fully understood. It has been reported that there is involvement of the host immune factors and viral factors. Several studies have shown that concentrations of cytokines/chemokines on blood are significantly increased during infection and viral factors are also involved in disease severity. Therefore, characterization of host gene expression profiles in response to dengue virus infection of different serotypes could provide input for understanding the pathogenesis of dengue. The purpose of this research was to determine expression profiles of the genes ( $m R N A$ ) of cytokines/chemokines as immune response that are released by monocyte derived macrophages (MDM) cells (host gene) exposed dengue viruses. Four dengue serotypes of Indonesia isolate were used in this study. Peripheral Blood Mononuclear Cells (PBMCs) were isolated from blood cells of healthy donors by Ficoll gradient centrifugation techniques and then differentiated into MDM cells. Quantitative real time RT-PCR was used to quantify expression levels of cytokine/chemokine-encoding genes from MDM cells infected dengue. Four cytokine/chemokine-encoding genes i.e IP-10, MCP-1, IL-10, and $M I P-1 \beta$ known involved in dengue pathogenesis. Measurement of the expression levels of cytokines/ chemokines showed that the dengue virus of serotypes DENV-1 and DENV-3 caused an increase in the expression of genes encoding cytokine IL-10 and chemokine IP-10 is higher than other serotypes. Further research is needed to better determine the pathogenesis of dengue disease.

Keywords: cytokines/chemokines, dengue, MDM cells, quantitative real time RT-PCR. 


\section{ABSTRAK}

Dengue merupakan salah satu penyakit arbovirus terpenting dunia. Pemahaman mengenai patogenesis dengue belum sepenuhnya diketahui. Telah dilaporkan bahwa ada keterlibatan antara faktor imun pejamu dan faktor virus. Beberapa studi telah menunjukkan bahwa konsentrasi sitokin/ kemokin dalam darah meningkat signifikan selama infeksi dan faktor virus terlibat pula dalam keparahan penyakit. Karakterisasi profil ekspresi gen pejamu sebagai respon terhadap infeksi virus dengue dengan serotipe yang berbeda dapat memberikan masukan untuk pemahaman patogenesis dengue. Penelitian ini bertujuan untuk mengetahui profil ekspresi gen penyandi sitokin/kemokin sebagai respon imun yang dilepaskan oleh sel monocyte derived macrophages (MDM) pejamu yang telah dipapar virus dengue. Empat serotype virus dengue isolat Indonesia digunakan dalam penelitian ini. Sel peripheral blood mononuclear cell (PBMC) diisolasi dari darah donor sehat dengan teknik sentrifugasi gradient Ficoll dan kemudian didiferensiasi menjadi sel MDM. Quantitative real-time RT-PCR digunakan untuk menentukan tingkat ekspresi gen penyandi sitokin/kemokin dari sel MDM yang terinfeksi virus dengue. Empat gen penyandi sitokin/kemokin yaitu IP-10, MCP-1, IL-10, dan MIP-1 $\beta$ diketahui berperan dalam patogenesis penyakit dengue. Pengukuran tingkat ekspresi sitokin/ kemokin menunjukkan bahwa virus dengue serotipe DENV-1 dan DENV-3 menyebabkan peningkatan ekspresi gen penyandi sitokin IL-10 dan kemokin IP-10 yang lebih tinggi dibandingkan serotipe lain. Penelitian lebih lanjut diperlukan untuk lebih mengetahui patogenesis penyakit dengue.

Kata kunci: dengue, quantitative real time RT-PCR, sel MDM, sitokin/kemokin.

\section{PENDAHULUAN}

Penyakit dengue merupakan penyakit yang penyebarannya paling cepat di antara penyakit dengan vektor nyamuk lainnya, dengan 50 sampai 100 juta kasus Demam Dengue (DD) dan 500.000 kasus Demam Berdarah Dengue (DBD)/Sindrom Renjatan Dengue (SRD) dilaporkan setiap tahun (Sariol et al. 2007).

Respon seluler in vitro terhadap infeksi virus dengue telah digunakan untuk memahami interaksi antara virus dan host/pejamu (Warke et al. 2003). Induksi terhadap ekspresi berbagai sitokin/kemokin secara in vitro juga telah diamati pada infeksi dengue terhadap berbagai galur sel primer (primary cell lineages) maupun established cell lines (Noisakran et al. 2010). Virus dengue dapat menginfeksi monosit/ makrofag manusia yang memicu sekresi sitokin
(Kou et al. 2008). Monosit/makrofag merupakan bagian dari sistem imun yang memiliki sifat fagosit dan berperan untuk mendeteksi serta menghancurkan patogen yang invasif. Sel monosit/makrofag yang menjadi target virus dengue akan berpengaruh pada modulasi sistem imun, salah satunya dengan sekresi sitokin (Sun et al. 2013).

Beberapa studi telah menunjukkan bahwa konsentrasi sitokin dan mediator lain meningkat signifikan selama infeksi dan diasosiasikan dengan keparahan penyakit (Fink et al. 2007). Kadar plasma interleukin-1 beta (IL-1 $\beta$ ), IL2, IL-4, IL-6, IL-7, IL-8 , IL-10, IL-13, IL-18, tumor growth factor-1 beta (TGF-1 $\beta$ ), tumor necrosis factor alpha (TNF- $\alpha)$, dan interferon gamma (IFN- $\gamma$ ) telah dibuktikan meningkat pada pasien dengan infeksi dengue berat, 
terutama pada pasien Sindrom Renjatan Dengue (SRD) (Bozza et al. 2008, Martina et al. 2009).

Penelitian ini bertujuan untuk mengetahui kemampuan virus dengue isolat Indonesia dalam menginduksi respon imun sel makrofag manusia dan untuk menentukan profil ekspresi gen penyandi sitokin/kemokin yang disekresikan oleh sel MDM manusia sehat yang dipapar oleh virus dengue dengan menggunakan metode quantitative real time reverse transcriptionpolymerase chain reaction (qRT-PCR). Hasil penelitian ini diharapkan dapat menambah informasi mengenai patogenesis penyakit dengue dan ekspresi sitokin tertentu dapat digunakan sebagai penanda keparahan penyakit dengue.

\section{BAHAN DAN METODE}

\section{Bahan}

Sampel virus yang digunakan adalah virus dengue dari keempat serotipe, yakni DENV-1 025, DENV-2 SE001, DENV-3 024, dan DENV-4 M010. Virus-virus tersebut merupakan virus galur Indonesia yang diisolasi dari pasien dengue. Sel yang digunakan adalah sel makrofag MDM yang dideferensiasi dari PBMC manusia sehat (kriterianya yaitu secara klinis tidak sedang mengalami gejala penyakit dengue maupun gejala penyakit lainnya, tidak memiliki riwayat penyakit autoimun, dan suhu badan normal $36,5-37,5^{\circ} \mathrm{C}$ ) yang diperoleh dari darah vena. Persetujuan etik penelitian diperoleh dari Komite Etik Penelitian Lembaga Biologi Molekuler Eijkman.

\section{Isolasi PBMC menggunakan teknik} sentrifugasi gradien Ficoll

Sel PBMC diisolasi dari darah vena donor sehat menggunakan teknik aseptik dan ditambahkan anti koagulan heparin dalam tabung Vacuette (Greiner Bio-One). Darah diencerkan dengan Phosphate-buffered Saline (PBS) $\mathrm{pH} 7,2$; tanpa kandungan ion $\mathrm{Mg}^{2+}$ dan $\mathrm{Ca}^{2+}$ (Gibco) dengan perbandingan 1:2. Larutan Ficoll(Ficoll-Paque PLUS) ditambahkan dengan perbandingan 2:3. Campuran disentrifugasi pada $400 \times \mathrm{g}, \quad 20^{\circ} \mathrm{C}$ selama 40 menit. Bagian buffy coat yang berisi PBMC dipindahkan ke dalam tabung sentrifugasi baru dan dicuci dengan PBS pH 7,2 sebanyak 3 kali volume buffy coat dan disentrifugasi pada $100 \mathrm{x} g, 4{ }^{\circ} \mathrm{C}$ selama 10 menit. Supernatan dibuang. Proses diulang 2 kali. Jumlah sel PBMC dihitung menggunakan haemocytometer (Improved Neubauer) dan viabilitas sel ditentukan menggunakan pewarnaan trypan blue (Bahunde et al. 2013).

\section{Isolasi monosit dan diferensiasi menjadi Monocyte-derived Macrophages (MDM) menggunakan metode adherence}

Fraksi sel monosit diisolasi dari sel PBMC berdasarkan kemampuan melekat pada permukaan flask kultur (adherent-type cells). Sel PBMC dikultur pada flask T-75 (Nunc, Falcon) dengan medium pertumbuhan 1X RPMI 1640 (Gibco) yang disuplementasi $10 \%$ FBS (Hyclone), 10 mM L-glutamine (Gibco), 100 U/ $\mathrm{ml}$ Penicillin (Gibco), $100 \mu \mathrm{g} / \mathrm{ml}$ Streptomycin (Gibco), dan 20 ng/ml M-CSF (Sigma). Sel diinkubasi pada suhu $37{ }^{\circ} \mathrm{C}, 5 \% \mathrm{CO}_{2}$ selama 9 hari. Sel monosit hasil kultur disebut Human Monocyte-derived Macrophages (MDM). 
Jumlah sel MDM dihitung dengan menggunakan haemocytometer dan viabilitas sel ditentukan menggunakan pewarnaan trypan blue.

\section{Paparan berbagai serotipe virus dengue pada sel MDM}

Sebanyak $1,4 \times 10^{5}$ sel MDM ditanam dalam sumuran 24-wells plate (Nunc) dalam medium pertumbuhan dan dibiarkan melekat pada dasar sumuran selama inkubasi pada suhu $37{ }^{\circ} \mathrm{C}, 5 \% \mathrm{CO}_{2}$ semalaman. Sel kemudian diinfeksi virus dengue DENV-1 025, DENV-2 SE001, DENV-3 024, dan DENV-4 M010 dengan kondisi 0,1 multiplicity of infection (moi) dalam medium inokulasi (1X RPMI 1640, 2\% FBS, 10 mM L-glutamine, $100 \mathrm{U} / \mathrm{ml}$ Penicillin dan 100 $\mu \mathrm{g} / \mathrm{ml}$ Streptomycin). Kontrol non infeksi dan lipopolisakarida (LPS) juga disertakan pada uji ini. Setelah periode absorbsi virus selama 2 jam pada suhu $37{ }^{\circ} \mathrm{C}, 5 \% \mathrm{CO}_{2}$, medium inokulasi dibuang. Sebanyak $500 \mu 1$ medium inokulasi kemudian ditambahkan ke setiap sumuran dan plate diinkubasi pada suhu $37{ }^{\circ} \mathrm{C}, 5 \% \mathrm{CO}_{2}$. Sel (pellet) dilisis menggunakan buffer RLT (Qiagen) setelah 48 jam dan segera disimpan pada suhu $-80^{\circ} \mathrm{C}$.

\section{Ekstraksi RNA dari sel MDM yang telah dipapar virus dengue}

Ekstraksi RNA dari sel MDM yang telah dipapar virus dengue dilakukan menggunakan RNEasy Mini Kit (Qiagen) sesuai petunjuk pembuat kit. Sel dilisis dengan buffer RLT (Qiagen). Dilakukan penambahan DNAse (Roche) pada sampel untuk membersihkan RNA dari DNA kontaminan. Total RNA masingmasing sampel diukur menggunakan Thermo Scientific NanoDrop ${ }^{\mathrm{TM}} 1000$ Spektrofotometer.

\section{Deteksi gen sitokin/kemokin menggunakan metode RT-PCR}

Sebanyak 110 ng RNA digunakan sebagai template pada langkah transkripsi balik (reversetranscription) menjadi cDNA menggunakan enzim Superscript III Reverse Transcriptase (Invitrogen-Life Technologies) dan primer OligodT (Promega), dengan kondisi reaksi yaitu $25{ }^{\circ} \mathrm{C}$ selama 5 menit, $42{ }^{\circ} \mathrm{C}$ selama 60 menit, dan $70{ }^{\circ} \mathrm{C}$ selama 10 menit. cDNA yang terbentuk kemudian diamplifikasi dalam langkah PCR menggunakan Taq DNA polymerase (Roche) dan sepasang primer masing-masing gen, yaitu primer forward dan primer reverse, dengan kondisi reaksi adalah tahap pertama 95 ${ }^{\circ} \mathrm{C}$ selama 2 menit, tahap kedua yaitu $95{ }^{\circ} \mathrm{C}$ selama 30 detik, $55^{\circ} \mathrm{C}$ selama 1 menit, dan 72 ${ }^{\circ} \mathrm{C}$ selama 1 menit 30 detik sebanyak 35 siklus, dan tahap ketiga $72{ }^{\circ} \mathrm{C}$ selama 10 menit. Sekuen primer yang digunakan disajikan pada Tabel 1. Keberadaan gen sitokin/kemokin dan gen pengkode $\beta$-actin terdeteksi dengan hasil positif berupa pita DNA hasil amplifikasi dengan ukuran sesuai pada Tabel 1 setelah dilakukan elektroforesis gel agarosa $1 \%$ (Bio-Rad) yang mengandung $200 \mathrm{ng} / \mathrm{ml}$ ethidium bromide (Sigma).

\section{Karakterisasi ekspresi gen penyandi sitokin/ kemokin sel MDM setelah dipapar virus menggunakan metode quantitative real time RT-PCR}

Tingkat ekspresi gen penyandi sitokin/ kemokin diukur dengan quantitative real time RT-PCR (Applied Biosystems) menggunakan SYBR Green select reaction mix (Applied Biosystems) sesuai petunjuk dari pembuat kit. Sebelum dilakukan pengukuran dengan 
quantitative real time RT-PCR, RNA hasil ekstraksi dari sel MDM dilakukan transkripsi balik (reverse transcription). Hasil cDNA yang didapat digunakan sebagai cetakan (template) pada pengukuran dengan quantitative real time RT-PCR menggunakan SYBR Green select reaction mix dan sepasang primer masingmasing gen, yaitu primer forward dan primer reverse. Kondisi reaksinya adalah tahap pertama $50{ }^{\circ} \mathrm{C}$ selama 2 menit, tahap kedua $95{ }^{\circ} \mathrm{C}$ selama 2 menit, dan tahap ketiga yaitu $95{ }^{\circ} \mathrm{C}$ selama 15 detik dan $60{ }^{\circ} \mathrm{C}$ selama 1 menit sebanyak 35 siklus. Sebagai gen normalisasi, digunakan gen endogenous/housekeeping yakni beta actin (-actin). Pengukuran dilakukan 2 kali ulangan dengan menyertakan kontrol tanpa cetakan cDNA.

\section{Analisis Statistik}

Uji statistik t-Test digunakan untuk membandingkan rerata antara kelompok uji yang terinfeksi dengan kontrol non-infeksi. Analisis statistik menggunakan piranti lunak SPSS 19.0 untuk Windows (SPSS Internasional).

\section{HASIL}

\section{Morfologi sel MDM}

Morfologi sel MDM diamati selama proses diferensiasi dari PBMC menjadi MDM. Perubahan morfologi selama diferensiasi dapat terlihat pada Gambar 1. Pada awal isolasi dari PBMC, sel-sel monosit berbentuk bulat. Perkembangan sel terlihat lambat sejak pertama isolasi hingga hari ke empat dan lima. Perkembangan sel sejak hari ke enam hingga hari ke sembilan terlihat cepat. Gambaran diferensiasi sel monosit menjadi MDM terlihat pada dan setelah hari ke enam, dimana bentuknya menjadi agak memanjang, berbentuk mirip fibroblast dan memiliki pseudopodia yang merupakan ciri khas dari makrofag (Gambar 1) (Sasmono dan Hume 2004).

\section{Gen sitokin/kemokin hasil deteksi dengan RT-PCR}

Sebelum dilakukan pengukuran tingkat ekspresi gen penyandi sitokin/kemokin dengan quantitative real time RT-PCR, primerprimernya dioptimasi terlebih dahulu dengan
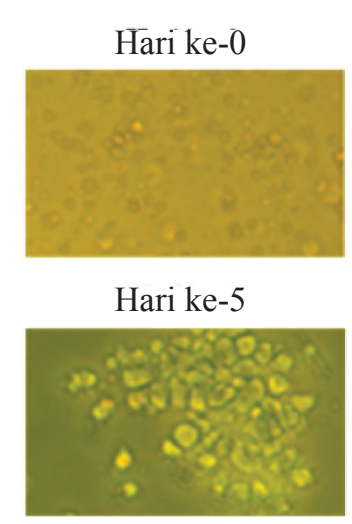

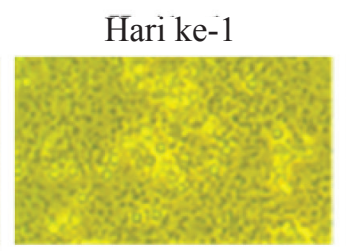

Hari ke-6

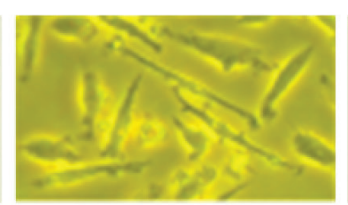

Hari ke-2

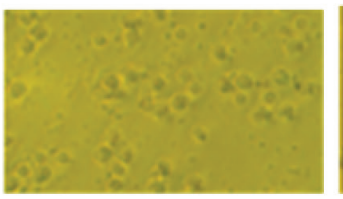

Hari ke-7

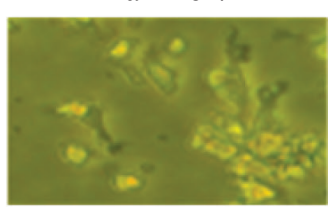

Hari ke-3

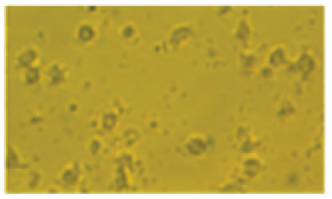

Hari ke-8

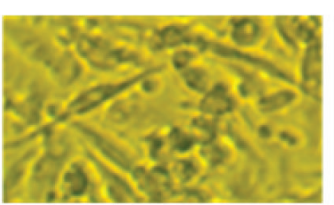

Hari ke-4

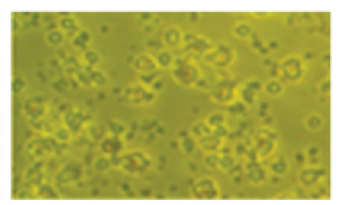

Hari ke-9

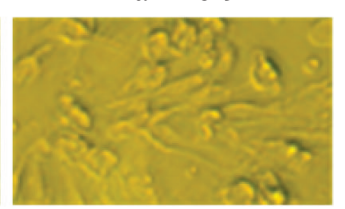

Gambar 1 Morfologi sel monosit dan proses diferensiasi menjadi MDM pada hari pertama sampai hari ke sembilan. Sel monosit berbentuk bulat, kecil, dan terdistribusi merata (hari ke-1 dan 2), sel monosit bertambah besar dan memiliki kontak satu sama lain (hari ke-3 dan 4), sel monosit membentuk kumpulan sel (hari ke-5), sel monosit berdiferensiasi menjadi MDM (hari ke-6 sampai hari ke-9). 


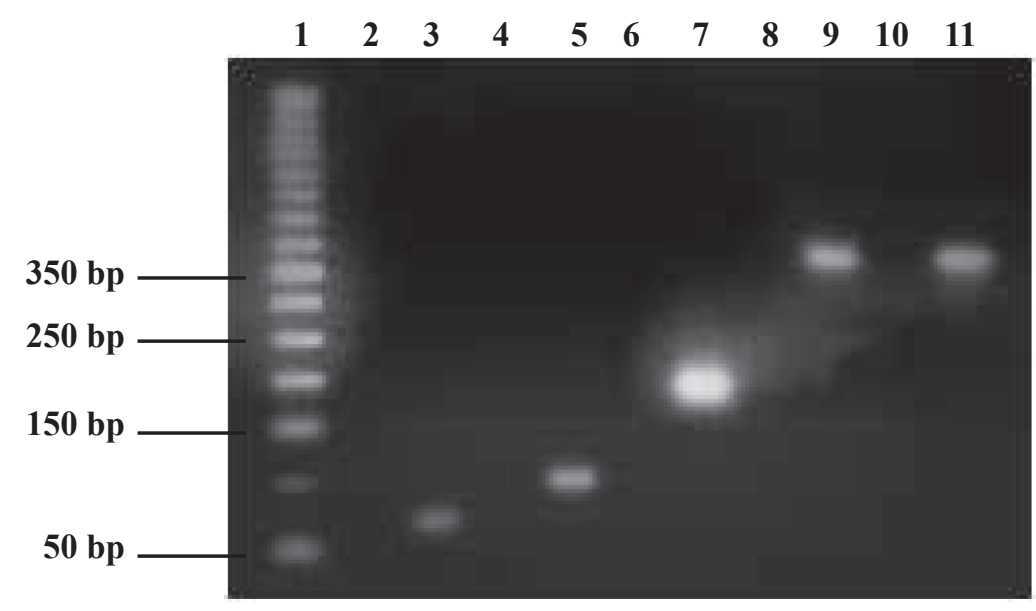

Gambar 2 Deteksi gen penyandi sitokin/kemokin menggunakan metode RT-PCR menghasilkan pita DNA: 1. Marka DNA $50 \mathrm{bp}$ (Invitrogen); 2. Negatif MIP-1 $\beta ; 3$. MIP-1 $\beta$ (61 bp); 4. Negatif MCP-1; 5. MCP-1 (91 bp); 6. Negatif IP-10; 7. IP-10 (177 bp); 8. Negatif IL-10; 9. IL-10 (352 bp); 10. Negatif $\beta$-actin; 11. $\beta$-actin (355 bp).

menggunakan mesin PCR. Hasil deteksi dapat dilihat pada Gambar 2. Berdasarkan hasil PCR tersebut, ke-empat gen penyandi sitokin/ kemokin (yakni IP-10, MCP-1, IL-10, dan MIP-1 $\beta$ ) dan gen pengkode $\beta$-actin berhasil diamplifikasi dan terdeteksi dengan adanya keberadaan pita-pita DNA seperti yang terlihat pada Tabel 1.

\section{Gen penyandi sitokin/kemokin sel MDM setelah dipapar virus menggunakan metode quantitative real time $\mathrm{RT}-\mathrm{PCR}$}

Pada penelitian ini, quantitative realtime RT-PCR digunakan untuk mendeteksi dan mengukur gen penyandi sitokin/kemokin manusia dari sel MDM pada 48 jam pasca infeksi virus dengue. Reaksi quantitative real time RT-PCR menggunakan kit SYBR Green select reaction mix dengan volume total 20

Tabel 1 Sekuen primer yang digunakan.

\begin{tabular}{|c|c|c|c|}
\hline No. & Gen & Sekuen primer & Referensi \\
\hline 1. & $\beta$-actin (355 bp) & $\begin{array}{c}\text { F: 5'-CATCTCTTGCTCGAAGTCCA-3' } \\
\text { R: 5'-ATCATGTTTGAGACCTTCAACA-3' }\end{array}$ & Jia et al. (2010) \\
\hline 2. & IP-10 (177 bp) & $\begin{array}{l}\text { F:5'-TTCAAGGAGTACCTCTCTCTAG-3' } \\
\text { R: 5'-CTGGATTCAGACATCTCTTCTC-3' }\end{array}$ & Fu et al. (2008) \\
\hline 3. & MCP-1 (91 bp) & $\begin{array}{l}\text { F: 5'-CATTGTGGCCAAGGAGATCTG-3' } \\
\text { R: 5'-CTTCGGAGTTTGGGTTTGCTT-3' }\end{array}$ & Fu et al. (2008) \\
\hline 4. & IL-10 (352 bp) & $\begin{array}{l}\text { F: 5'-ATGCCCCAAGCTGAGAACCAAGACCCA-3' } \\
\text { R: 5'-TCTCAAGGGGCTGGGTCAGCTATCCCA-3' }\end{array}$ & Malefyt et al. (1991) \\
\hline 5. & MIP-1 $\beta$ (61 bp) & $\begin{array}{c}\text { F: 5'-CTGTGCTGATCCCAGTGAATC-3' } \\
\text { R: 5'-TCAGTTCAGTTCCAGGTCATACA-3' }\end{array}$ & Wolff et al. (2011) \\
\hline
\end{tabular}


$\mu 1$ dilakukan dengan perulangan duplo dan menyertakan kontrol non-template (NTC). Data yang dihasilkan berupa nilai $\mathrm{C}_{\mathrm{T}}$ (threshold cycle) dari masing-masing gen penyandi sitokin/ kemokin dan gen endogenous/housekeeping yaitu beta actin ( $\beta$-actin) sebagai gen normalisasi. Selisih nilai $\mathrm{C}_{\mathrm{T}}$ di antara masingmasing gen penyandi sitokin/kemokin dengan gen normalisasi digunakan untuk menentukan besarnya tingkat ekspresi gen penyandi sitokin/ kemokin, yang kemudian hasilnya dibandingkan dengan selisih nilai $\mathrm{C}_{\mathrm{T}}$ antara kontrol non-infeksi dan gen normalisasi.

Ekspresi empat gen penyandi sitokin/ kemokin kemudian dianalisis menggunakan uji stastistik t-Test untuk mengukur tingkat ekspresi gen penyandi sitokin/kemokin kelompok terinfeksi terhadap kontrol non-infeksi. Tingkat ekspresi yang signifikan adalah untuk gen IP-10 dan IL-10 yang masing-masing mencapai 14 dan 16 kali pada sel MDM yang terinfeksi DENV-1 025, dan pada sel MDM yang terinfeksi DENV3024 mencapai 7 dan 9 kali jika dibandingkan dengan kontrol non-infeksi yang dapat dilihat pada Gambar 3.

\section{PEMBAHASAN}

Penyakit dengue dibagi menjadi demam dengue (DD), demam berdarah dengue (DBD) dan sindrom renjatan dengue (SRD). Patogenesis DBD atau SRD bersifat kompleks dan belum diketahui. Beberapa hipotesis mengenai patogenesis infeksi virus dengue telah diajukan, termasuk patogenesis virus akibat

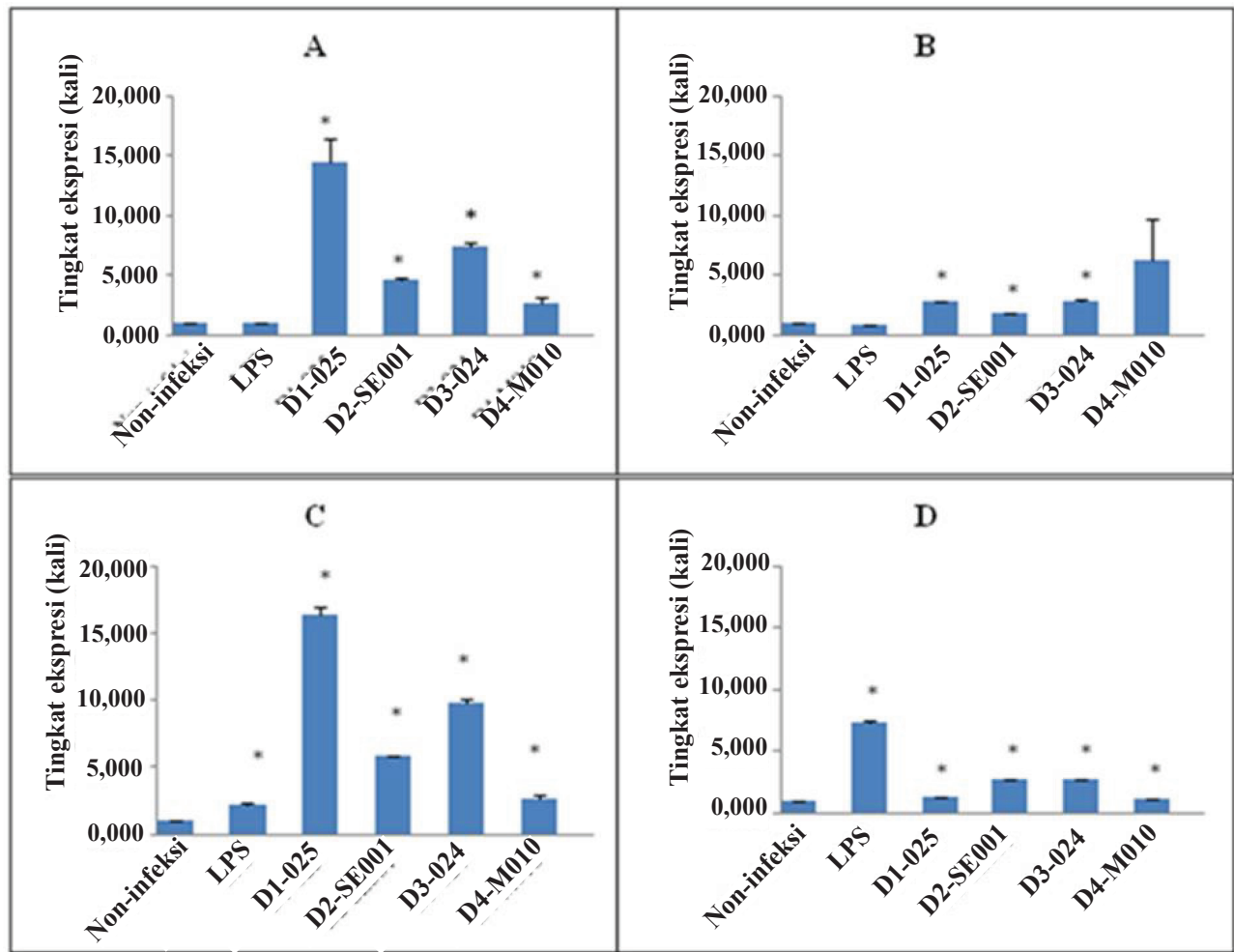

Gambar 3 Ekspresi empat gen penyandi sitokin/kemokin akibat paparan berbagai serotipe virus dengue. A. IP10, B. MCP-1, C. IL-10, dan D. MIP-13. Error bar menunjukkan standard error of means (SEM) untuk perulangan duplo. ${ }^{*} \mathrm{p}<0,05$ berdasarkan perbandingan rerata antara kelompok terinfeksi dengan non-infeksi menggunakan analisis statistik t-Test. 
faktor virus dan imunopatogenesis akibat dari faktor pejamu yang keduanya memiliki peran penting pada manifestasi terjadinya DBD/ SRD, seperti perdarahan, trombositopenia, kebocoran plasma dan kegagalan organ (Green dan Rothman 2006).

Pemahaman mengenai imunopatogenesis dengue terkadang mengalami kesulitan karena belum adanya hewan coba yang sesuai. Penggunaan sel imun seperti PBMC dan MDM dalam infeksi virus secara ex vivo telah dikembangkan untuk memahami interaksi virus pejamu. Sel-sel imun monosit dan makrofag, sel dendritik, dan sel endotel juga telah dilaporkan sebagai pejamu potensial untuk virus dengue (Warke et al. 2003; Kou et al. 2008; Becerra et al. 2009). Sel makrofag berperan diantaranya dalam. Sekresi protein-protein yang terlibat dalam proses imunologis tubuh, seperti sitokin dan kemokin. Sel PBMC manusia terdiri atas 70 $\%$ sel limfosit T, $15 \%$ limfosit B, $10 \%$ sel natural killer (NK), $5 \%$ monosit dan $1 \%$ sel dendritik (Delves et al. 2006). Secara in vitro, makrofag bisa diperoleh dengan mengisolasi monosit dari sel PBMC yang jumlahnya sekitar $5 \%$ dari sel tersebut. Makrofag yang didiferensiasi secara in vitro biasa disebut dengan monocyte derived macrophages (MDM) (Hashimoto et al. 1999).

Selain itu telah dilaporkan bahwa sel makrofag merupakan target awal infeksi virus dengue. Hubungan virus dengue yang menginfeksi makrofag secara in vitro telah diteliti dapat menginduksi perubahan permeabelitas pada sel endotel umbilikal manusia primer (HUVEC). Percobaan dilakukan dengan mengkoleksi supernatan dari makrofag yang diinfeksi DENV-2 dan kemudian dipaparkan pada sel HUVEC ternyata dapat meningkatkan permeabelitas lapisan monolayer HUVEC tanpa menginfeksi sel HUVEC tersebut, hasil ini diduga berhubungan dengan kebocoran vaskuler dan keparahan penyakit menjadi DBD/ RSD (Carr et al. 2003).

Sejumlah penelitian menunjukkan bahwa sel imun, baik sel imun bawaan maupun sel imun adaptif yang teraktivasi akibat infeksi oleh virus dengue akan melepaskan sitokin yang berlebihan pada beberapa keadaan sehingga dapat menimbulkan kebocoran plasma yang berakibat terjadinya keparahan dengue (Bozza et al. 2008).

Identifikasi profil sitokin pada pasien dengue telah dilaporkan pada beberapa penelitian, dan hasil ini sangat bermanfaat untuk karakterisasi pola respon imun secara in vivo dan dapat menjadi acuan untuk mengetahui pasien dengan resiko yang dapat berkembang menjadi manifestasi berat. Perubahan pada penanda biologis telah dipelajari dan dilaporkan secara ekstensif dengan fokus pada identifikasi parameter biologis pada sampel klinis yang berbeda antara kasus dengue berat dan ringan (Srikiatkhachorn dan Green 2010).

Sitokin merupakan protein sistem imun yang mengatur interaksi antar sel dan memacu reaktivitas imun, baik pada imunitas bawaan maupun adaptif. Sitokin merupakan protein pembawa pesan kimiawi atau perantara dalam komunikasi antar sel yang sangat poten. Jadi sitokin berperan dalam aktivasi sel $\mathrm{T}$, sel $\mathrm{B}$, monosit, makrofag, inflamasi dan induksi sitotoksisitas. Pada tahun 1979, suatu konsensus sekelompok peneliti memperkenalkan istilah interleukin. Interleukin adalah suatu protein bagian dari kelompok protein dengan berat molekul 4-50 kDa. Bagian dari keluarga interleukin adalah sitokin kemoatraktif atau kemokin, yang memiliki berat molekul 4-16 
kDa. Kemokin berfungsi mengontrol adhesi, kemotaktis dan aktivasi berbagai jenis leukosit (Abbas et al. 2012). Produksi sitokin yang terjadi akibat infeksi virus dengue pada sel imun memiliki kontribusi pada terjadinya manifestasi klinis penyakit.

Pada penelitian ini, tingkat ekspresi gengen penyandi sitokin/kemokin dipelajari secara in vitro dengan menggunakan makrofag yang diisolasi dari manusia sehat dan diinfeksi dengan virus dengue isolat Indonesia. Proses diferensiasi makrofag dari monosit pada penelitian ini diamati secara morfologis. Morfologi sel yang mempunyai ciri-ciri sebagai makrofag bisa diamati mulai hari keenam diferensiasi. Terlihat bentuk sel yang seperti fibroblast dan mempunyai pseudopodia (Gambar 1), yang menunjukkan bahwa sel monosit telah berhasil didiferensiasi menjadi makrofag (Sasmono dan Hume 2004). Sel-sel makrofag (MDM) ini kemudian diinfeksi dengan virus dengue untuk menentukan ekspresi sitokin/kemokinnya.

Profil ekspresi gen penyandi sitokin/ kemokin akibat paparan virus dengue menunjukkan tingkat ekspresi yang beragam untuk setiap serotipe (Gambar 3). Analisis statistik menunjukkan adanya perbedaan signifikan pada semua serotipe dibandingkan kontrol non-infeksi yaitu pada profil ekspresi IP-10, IL-10, dan MIP-1 $\beta$. Profil ekspresi MCP1, serotipe DENV-4 tidak menunjukkan adanya perbedaan signifikan jika dibandingkan dengan kontrol non-infeksi.

$$
\text { Interleukin 10/IL-10 merupakan }
$$
sitokin yang memiliki efek pleiotropic dalam imunoregulasi dan inflamasi. Virus dengue menyebabkan produksi sitokin anti-inflamasi IL-10 lebih tinggi pada pasien DBD dan SRD yang parah dibandingkan dengan pasien DD ringan (Lin et al. 2012). IL-10 memberikan kontribusi untuk patogenesis penyakit dengue dengan menghambat respon spesifik sel $\mathrm{T}$ efektor dengan virus dengue (Malavige et al. 2013). IL-10 memiliki peran penting pada patogenesis virus dengue, menghasilkan fungsi imunosupresif yang menyebabkan resistensi sitokin IFN, diikuti kegagalan pembersihan virus oleh sistem imun dan infeksi persisten pada infeksi viral akut (Tsai et al. 2013). IL10 dapat menyebabkan disfungsi limfosit yang terjadi pada pasien dengue selama tahap awal infeksi. Pasien yang memiliki penurunan jumlah trombosit (trombositopenia) telah dikaitkan dengan keberadaan IL-10 (Brasier et al. 2012). Selain itu, tingkat IL-10 lebih tinggi pada pasien dengue terinfeksi sekunder dibandingkan pada pasien dengue yang terinfeksi primer (Tang et al. 2010; Yeh et al. 2006). Induksi IL-10 dikaitkan dengan infeksi dengue yang parah dan berpotensi sebagai biomarker untuk infeksi dengue akut (Butthep et al. 2012; Brasier et al. 2012). Secara khusus, ekspresi IL-10 bertindak sebagai prediksi penanda kematian bagi penderita DBD (Chen et al. 2006).

IP-10 (CXCL10) merupakan kemokin pro inflamasi yang terinduksi ketika infeksi virus dengue. Induksi ekspresi IP-10 telah dilaporkan pada respon dendritic cells dan sel line primer terhadap virus dengue secara in vitro (Becerra et al. 2009). Peningkatan konsentrasi IP-10 telah ditemukan dalam serum pasien terinfeksi dengue pada dua studi kohort di Venezuela (Becerra et al. 2009) dan Singapura (Fink et al. 2006). Hal ini menimbulkan dugaan bahwa IP-10 memiliki kemampuan untuk menghambat ikatan virus pada sel target in vitro melalui kompetisi pada heparin sulfat pada permukaan sel (Hsieh et al. 2006; Chen et al. 2006). Berdasarkan 
hasil penelitian ini, ekspresi sitokin IL-10 dan kemokin IP-10 dari sel MDM didominasi oleh serotipe 1 dan 3 .

\section{Monocyte Chemoattractant Protein-1} (MCP-1) adalah kemokin yang meregulasi pergerakan monosit/makrofag (Deshmane et al. 2009) dan kemokin ini telah dikaitkan dengan perubahan permeabilitas sel endotel, di mana perubahan terjadi pada tight junction sel endotel pembuluh darah dan menyebabkan kebocoran plasma pada pasien dengue (Dewberry et al. 2003; Sierra et al. 2010). Dalam studi pada pasien peningkatan konsentrasi MCP1 ditemukan pada fase demam pasien dengan tanda-tanda peringatan dibandingkan dengan orang sehat menunjukkan kemokin ini sebagai penanda keparahan penyakit (Rathakrishnan et al. 2012; Srikiatkhachorn dan Green 2010).

Macrophage inflammatory Protein 1 beta (MIP-1 $\beta$ ) merupakan kemokin yang diproduksi oleh makrofag pada manusia (Abbas et al. 2012). Kemokin ini berperan penting pada respon imun yang berhubungan dengan infeksi dan inflamasi. Kemokin ini mengaktivasi granulosit manusia termasuk netrofil, basofil, dan eosinofil yang dapat menyebabkan inflamasi netrofil. Bozza et al. (2008) mendapatkan MIP$1 \beta$ berhubungan dengan keparahan penyakit dimana peningkatan MIP-1 $\beta$ terlihat pada pasien dengue derajat ringan.

Berdasarkan hasil penelitian ini bahwa terjadi peningkatan ekspresi keempat gen penyandi sitokin/kemokin (IL-10, MCP-1, IP10, dan MIP-1 $\beta$ ) pada sel MDM manusia sehat yang dipapar virus dengue dibandingkan dengan kontrol non-infeksi. Virus dengue serotipe 1 (DENV-1) dan 3 (DENV-3) menyebabkan peningkatan ekspresi yang signifikan untuk gen penyandi IL-10 dan IP-10. Hasil ini menandakan bahwa ada perbedaan kemampuan dari masingmasing serotipe virus dengue dalam menginduksi respon imun pejamu. Penelitian ini masih dalam tahap awal dan hanya menggunakan satu isolat virus untuk setiap serotipenya, sehingga untuk mendapatkan hasil yang lebih informatif, perlu dilakukan penelitian lebih lanjut, diantaranya bisa dilakukan dengan menambah jumlah isolat virus dengue untuk setiap serotipe yang berasal dari berbagai daerah di Indonesia.

\section{UCAPAN TERIMA KASIH}

Penulis mengucapkan terima kasih kepada Laboratorium Dengue, Lembaga Biologi Molekuler Eijkman yang telah mendanai penelitian ini.

\section{DAFTAR PUSTAKA}

Abbas AK, Lichtman AH, Pillai S. 2012. Cellular and Molecular Immunology. $7^{\text {th }} \mathrm{ed}$. United States of America: Elsevier.

Bahunde F, Awoyode R, Fields B, McLean P, Tambwe C, Johnson N. 2013. Creating Evidence-based Procedures Out of Establised Processes: Validation of FicollPlaque $^{\mathrm{TM}}$ Centrifugation for Isolation of Peripheral Blood Mononuclear Cells. In Precision Bioservices, Inc. Frederick. MD Viability and Purity of Cell.

Beccera A, Warke RV, Martin K, Xhaja K, de Bosch N, Rothman AL, Bosch I. 2009. Gene expression profiling of dengue infected human primary cells identifies secreted mediators in vivo. J Med Virol. 81(8):14031411.

Bozza FA, Cruz OG, Zagne SM, Azeredo EL, Nogueira RM, Assis EF, Bozza PT, Kubelka CF. 2008. Multiplex cytokine profile from dengue patients: MIP-1 beta and IFN-gamma as predictive factors for severity. BMC Infect Dis. 8:86.

Brasier AR, Ju H, Garcia J, Spratt HM, Victor SS, Forshey BM, Halsey ES, Comach G, Sierra 
G, Blair PJ, Rocha C, Morrison AC, Scott TW, Bazan I, Kochel TJ. 2012. A threecomponent biomarker panel for prediction of dengue hemorrhagic fever. Am J Trop Med Hyg. 86:341-348.

Butthep P, Chunhakan S, Yoksan S, Tangnararatchakit K, Chuansumrit A. 2012. Alteration of cytokines and chemokines during febrile episode sassociated with endothelial cell damage and plasma leakage in denguehemorrhagic fever. Pediatr Infect Dis J. 31(12):e232-e238.

Carr JM, Hocking $\mathrm{H}$, Bunting $\mathrm{K}$, Wright $\mathrm{PJ}$, Davidson A, Gamble J, Burrell CJ, Li P. 2003. Supernatants from dengue virus type2 infected macrophages induce permeability changes in endhotelial cell monolayers. $J$ Med Virol. 69(4):521-528.

Chen LC, Lei HY, Liu CC, Shiesh SC, Chen SH, Liu HS, Lin YS, Wang ST, Shyu HW, Yeh TM. 2006. Correlation of serum levels of macrophage migration inhibitory factor with disease severity and clinical outcome in dengue patients. Am J Trop Med Hyg. 74:142-147.

Delves PJ, Martin SJ, Burton DR, Roitt IM. 2006. Roitt's Essential Immunology. $11^{\text {th }}$ ed. Blackwell Publishing.

Deshmane SL, Kremlev S, Amini S, Sawaya BE. 2009. Monocyte Chemoattractant Protein-1 (MCP-1): An overview. Interferon Cytokine Res. 29(6):313-326

Dewberry RM, Crossman DC, Francis SE. 2003. Interleukin-1 receptorantagonist (IL-1RN) genotype modulates the replicative capacity of humanendothelial cells. Circ Res. 92: $1285-1287$.

Fink J, Gu F, Ling L, Tolfvenstam T, Olfat F, Chin KC, Aw P, George J, Kuznetsov VA, Schreiber M, Vasudevan SG, Hibberd ML. 2007. Host gene expression profiling of dengue virus infection in cell lines and pasients. PloS Negl Trop Dis. 1(2):e86.

Fink J, Gu F, Vasudevan SG. 2006. Role of T cells, cytokine and antibody in dengue fever and dengue haemorrhagic fever. Rev Med Virol. 16(4):263-275.

Fu Q, Chen X, Cui H, Guo Y, Chen J, Shen N, Bao C. 2008. Association of elevated transcript levels of interferon-inducible chemokines with disease activity and organ damage in systemic lupus erythematosus patients. Arthritis Research \& Therapy.10(5):1-10.

Green S, Rothman A. 2006. Immunopathological mechanisms in dengue and dengue hemorrhagic fever. Curr. Opin. Infect. Dis. 19:429-236.

Hashimoto S, Suzuki T, Dong HY, Yamazaki N, Matsushima K. 1999. Serial analysis of gene expression in human monocytes and macrophages. Blood. 94: 837-844.

Hsieh MF, Lai SL, Chen JP, Sung JM, Lin YL, WuHsieh BA, Gerard C, Luster A, Liao F. 2006. Both CXCR3 and CXCL10/IFN-Inducible Protein 10 are required for resistance to primary infection by dengue virus. $J$ Immunol. 177:1855-1863.

Jia JB, Wang WQ, Sun HC, Zhu XD, Liu L, Zhuang PY, Zhang W, Xu HX, Kong LQ, Lu L, Wu WZ, Wang L, Tang ZY. 2010. High Expression of Macrophage Colony-Stimulating Factor-1 Receptor in Peritumoral Liver Tissue Is Associated with Poor Outcome in Hepatocellular Carcinoma After Curative Resection. The Oncologist. 15:732-743.

Kou Z, Quinn M, Chen H, Rodrigo WW, Rose RC, Schlesinger JJ, Jin X. 2008. Monocytes, but not $\mathrm{T}$ or $\mathrm{B}$ cells, are the principal target cells for dengue virus (DV) infection among human peripheral blood mononuclear cells. J Med. Virol. 80: 134-146.

Lin CF, Chuang YJ,Lin YS, Wan SW, Chen CL. 2012. The molecular mechanism of dengue virusinduced IL-10 production in monocytes. The Journal of Immunology. 168(15): 188.

Malavige GN, Jeewandara C, Alles KM, Salimi M, Gomes L, Kamaladasa A, Jayaratne SD, Ogg GS. 2013. Suppression of Virus Specific 
Immune Responses by IL-10 in Acute Dengue Infection. PLoS Negl Trop Dis 7(9): e2409. doi:10.1371/journal.pntd.0002409.

Malefyt R, Abrams J, Bennett B, Figdor CG, de Vries JE. 1991. Interleukin-10 (IL-10) inhibits cytokine synthesis by human monocytes: An autoregulatory role of IL-10 produced by monocytes. J Exp Med. 174:1209-1220.

Martina BE, Koraka P, Osterhaus AD. 2009. Dengue virus pathogenesis: an integrated view. Clin Microbiol Rev. 22(4):564-581.

Noisakran S, Onlamoon N, Songprakhon P, Hsiao H-M, Chokephaibulkit K, Perng GC. 2010. Cells in dengue virus infection in vivo. $A d v$ Virol. Article ID 164878, 15 pages.

Rathakrishnan A, Wang SM, Hu Y, Khan AM, Ponnampalavanar S, Lum LC, Manikam R, Sekaran SD. 2012. Cytokine expression profile of dengue patients at different phases of illness. Plos One. 7(12): e52215. doi:10.1371/journal.pone.0052215.

Sariol CA, Munoz-Jordan JL, Abel K, Rosado LC, Pantoja P, Giavedoni L, Rodriguez IV, White LJ, Martinez M, Arana T, Kraiselburd EN. 2007. Transcriptional activation of interferon-stimulated genes but not of cytokine genes after primary infection of rhesus Macaques with dengue virus type 1. Clinical and Vaccine Immunology. 14(6):756-766.

Sasmono RT, Hume DA. 2004. The Biology of Macrophages. Dalam "The Innate Immunity Response to Infection", S.E. Kaufmann, R. Medzhitov and S. Gordon (Eds). The American Society of Microbiology press.

Sierra B, Perez AB, Vogt K, Garcia G, Schmolke K, Aguirre E, Alvarez M, Volk HD, Guzman MG. 2010. MCP-1 and MIP-1 alpha expression in a model resembling early immune response to dengue. Cytokine. 52: $175-183$.

Srikiatkhachorn A, Green S. 2010. Markers of dengue disease severity. Curr. Top. Microbiol. 3:1322.
Sun P, Kochel TJ. 2013. The Battle between Infection and Host Immune Responses of Dengue Virus and Its Implication in Dengue Disease Pathogenesis. Sci World J.

Tang Y, Kou Z, Zhang F, Yao X, Liu S, Ma J, Zhou Y, Zhao W, Tang X, Jin X. 2010. Both viremia and cytokine levels associate with the lack of severe disease in secondary dengue 1 infection among adult Chinese patients. PLoS One. 5 (12):e15631.

Tsai TT, Chuang YJ, Lin YS, Wan SW, Chen CL, Lin CF. 2013. An emerging role for the anti inflammatory cytokine interleukin-10 in dengue virus infection. Journal of Biomedical Science. 20:40.

Warke RV, Xhaja K, Martin KJ, Fournier MF, Shaw SK, Brizuela N, de Bosch N, Lapointe D, Ennis FA, Rothman AL, Bosch I. 2003. Dengue virus induces novel change in gene expression of human umbilical vein endothelial cells. J Virol. 77(21):1182211832.

Wolff HA, Rolke D, Rave-Fränk M, Schirmer M, Eicheler W, Doerfler A, Hille A, Hess CF, Matthias C, Rödel RMW, Christiansen H. 2011. Analysis of chemokine and chemokine receptor expression in squamous cell carcinoma of the head and neck (SCCHN) cell lines. Radiat Environ Biophys. 50:145154.

Yeh WT, Chen RF, Wang L, Liu JW, Shaio MF, Yang KD. 2006. Implications ofprevious subclinical dengue infection but not virus load in dengue hemorrhagic fever. FEMS Immunol Med Microbiol. 48:84-90. 